\title{
What Governs Directors' Monitoring Behavior in China? The Influence of Director Social Identification, Learning Goal Orientation, and Avoidance Orientation
}

\author{
Alessandra Capezio \\ Research School of Management, L. F. Crisp Building (26), Australian National University, \\ Canberra, 0200, Australia \\ Lin Cui * \\ Research School of Management, L. F. Crisp Building (26), Australian National University, \\ Canberra, 0200, Australia \\ Helen Wei Hu \\ Department of Management \& Marketing, Level 10, 198 Berkeley St, University of Melbourne, \\ Melbourne, VIC 3010, Australia

\section{John Shields} \\ The University of Sydney Business School, H03 - Institute Building, The University of Sydney, \\ NSW 2006, Australia \\ * Corresponding author \\ Email: lin.cui@anu.edu.au Phone: +61261256190Ｆax: + 61261258796
}

\section{AKNOWLEDGEMENTS}

This research was funded by the Australian National University's College of Business and Economics internal research grant scheme. We thank George Chen, Howard Dick, Bill Harley, Amy Hillman, David McKendrick, and Simon Restubog for their valuable suggestions to improve this manuscript. 


\title{
Author Biographies
}

\author{
Alessandra Capezio \\ Alessandra Capezio is a Lecturer in the Research School of Management at the Australian \\ National University. Her research focuses on career development, social identification, \\ leadership, and corporate governance. Her research has been published in the Journal of \\ Management Studies, and Journal Career Assessment.
}

\section{Lin Cui}

Lin Cui is Senior Lecturer in International Business at the Research School of Management, the Australian National University. He received his $\mathrm{PhD}$ in international business from the Australian National University in 2008. His research centers on internationalization of emerging economy firms and has been published in leading journals such as Journal of International Business Studies and Asia Pacific Journal of Management.

\section{Helen Wei Hu}

Helen Wei Hu is Senior Lecturer in Strategy and International Business at the Department of Management and Marketing, the University of Melbourne. Helen received her PhD in international business from Monash University and she was an Honorary Research Fellow at Monash University. Her research focuses on corporate governance of emerging economy firms. Her work has been published or is forthcoming in Strategic Management Journal and Asia Pacific Journal of Management, among others.

\section{John Shields}


John Shields is Professor of Human Resource Management and Organisational Studies in the Discipline of Work and Organisational Studies at the University of Sydney Business School... His principal areas of research, publication and teaching include performance management, reward management, executive remuneration and corporate governance, and business and labour history. In the field of human resource management, his book publications include Managing Employee Performance and Reward, Cambridge University Press, 2007, and Human Resource Management: Strategy and Practice, $8^{\text {th }}$ edition, 2013 (co-authored with Alan Nankervis, Marian Baird and Jane Coffey). 


\title{
What Governs Directors' Monitoring Behavior in China? The Influence of Director Social Identification, Learning Goal Orientation, and Avoidance Orientation
}

\begin{abstract}
Drawing together literature on corporate governance, organizational behavior, and educational psychology, and using survey data from a sample of 300 Chinese company directors, this study examines the mediating role of director learning goal orientation in linking two widelyacknowledged director social identifications (identification with the organization and identification with executive-agents) and a key director task behavior, namely the monitoring of executive-agents. We also investigate the moderating role of director avoidance orientation in influencing this mediation since a predisposition to avoid loss of 'face' is widely posited as having particular relevance in the Chinese context. Results show, firstly, that directors with stronger organizational identification monitor executive-agents more diligently than those with stronger executive-agent identification. Secondly, we find that while learning goal orientation mediates the positive effects of both organizational identification and executive-agent identification on monitoring, the mediated indirect effect of organizational identification on monitoring is stronger than the mediated indirect effect of executive-agent identification on monitoring. Thirdly, results show that the indirect effects are stronger when director avoidance orientation is low. These findings underscore the importance of director social identification and learning goal orientation in inducing director monitoring in the Chinese context, as well as the worth of selecting directors who exhibit a low disposition to avoidance.
\end{abstract}

\section{Keywords}

Board of directors, monitoring, learning goal orientation, social identification. 


\section{INTRODUCTION}

Monitoring is a key governance role of the corporate board. Monitoring refers to the responsibility of a board and its directors to performance-manage and reward top executives to ensure that executive decisions and actions support shareholder wealth creation (Hillman \& Dalziel, 2003; Jensen \& Meckling, 1976; Johnson, Daily, \& Ellstrand, 1996). The empirical research on director monitoring is dominated by studies undertaken in North America and Europe (e.g., Golden-Biddle \& Rao, 1997; Stern \& Westphal, 2010; Westphal \& Stern, 2007; see Huse, 2009 for a review). Far fewer studies have been conducted in rapidly developing economies, such as China and India. While some studies that have been conducted in such contexts report that boards are inactive in their monitoring role (e.g., Hu, Tam, \& Tan, 2010; Jackling \& Johl, 2009; Rajagopalan \& Zhang, 2008; Su, Xu, \& Phan, 2008), the findings overall remain inconclusive (Singh \& Gaur, 2009; Peng, 2004; van Essen, van Oosterhout, \& Carney, 2012). This highlights the need for further research on the determinants of director monitoring activity in rapidly-emerging non-Western socio-economic and corporate governance contexts. Rather than assume that directors in these contexts simply neglect monitoring, it is important to consider factors that may affect director motivation to engage in monitoring in these settings. Such research also stands to offer a more comprehensive understanding of the monitoringrelated motivations of individual directors and, in turn, a more genuinely global understanding of this governance function at the individual director-level (Kumar \& Zattoni, 2013).

Rethinking the relationship between director social identification, goal orientation, and monitoring behavior 
Recent research has proposed that one of the key factors influencing a director's motivation to monitor is their pattern of role-related social identifications (Golden-Biddle \& Rao, 1997; Hillman, Nicholson, \& Shropshire, 2008). These identifications are defined by Ashforth and Mael (1989) as the individual's perception of oneness with or belongingness to various boardrelevant social categories. Prominent theories of corporate governance, such as agency theory and managerial power theory, also suggest that director identifications with the organization and executive-agents are salient to directors' motivation to monitor executives (Brickson, 2007; Cooper \& Thatcher, 2010). Despite the purported salience of director social identifications as predictors of director monitoring, there has been very little empirical testing of director identification-monitoring relationships. This is the case even in the North American and European contexts where most empirical research on boards has thus far been concentrated. Furthermore, behavioral patterns of directors in Asian corporate governance contexts may reflect governing mechanisms and standards that differ from those in developed western contexts. Thus, it is imperative to develop an understanding of directors' motivation to monitor that takes account of their situated governance structures and standards.

Empirically, very little research attention has been given to the psychological mechanisms linking director identifications and monitoring behavior. Research on achievement motivation suggests that an individual's learning goal orientation may be an important predictor of task engagement (Vandewalle, 1997). Initially developed as a concept in educational psychology, learning goal orientation is a form of achievement motivation that leads individuals to devote a higher level of effort and attention to developing their role capabilities which, in turn, increases their task performance (Button et al., 1996; DeShon \& Gillespie, 2005; Vandewalle, 2001; Elliot \& Dweck, 1988; Lawrence \& Lorsch,1967) Individuals with high learning goal 
orientation seek out and act on developmental feedback from other stakeholders and strive consistently to strengthen their repertoire of skills and know-how (Chughtai \& Buckley, 2010). Adapting the insights offered by Dweck and Leggett (1988), Vandewalle (1997, 2001) and others from the field of educational psychology, we suggest that a director's role-specific learning goal orientation may be an important self-regulatory mechanism that can lead to heightened attention to monitoring. Such individuals also gauge their effectiveness, not in terms of what others may happen to say about their performance achievements but, rather, in terms of the degree of effort they themselves expend in applying and augmenting their performance capabilities (Vandewalle, 1997, 2001). In other words, a director's monitoring behavior might be strongly affected by his/her role-specific goal orientation. While a relationship between learning goal orientation and job performance has been identified in prior research in the field of human resource management (e.g. Chughtai \& Buckley, 2010), the literature on boards and governance is largely silent on the influence of director learning orientation on the relationship between director identifications and their monitoring behavior.

To address these shortcomings in prior research on boards and governance, our study seeks to offer an understanding of the factors that drive director monitoring that is both more refined that prior research and more attuned to a key non-western context; specifically, to China. It does so by drawing on and integrating both goal orientation theory and social identity theory to develop and test a moderated mediation model which jointly examines three hypothesized effects. Firstly, we test the relative direct effects of (i) identification with the organization and (ii) identification with executive-agents on director monitoring, to reveal whether directors with a stronger identification with the organization monitor more diligently than those directors with a stronger identification with executive-agents. Secondly, we test the mediating effect of director 
learning goal orientation on the relationship between each of these director social identifications and monitoring, including the relative strength of these indirect effects. Thirdly, we test whether a director's avoidance orientation, a dispositional tendency to avoid negative judgment of one's ability (Elliot, 1999), moderates the indirect effect of the two social identifications on monitoring via learning goal orientation.

\section{Broadening the research context: corporate governance, cultural values and director monitoring in China}

As well as addressing recent calls for new lines of research that explore board cognition and behavior in general (Boyd, Haynes, \& Zona, 2011; Capezio, Shields, \& O'Donnell, 2011; Finkelstein \& Mooney, 2003; Huse, 2007; Hillman et al., 2008), our study adds to the emerging body of research on corporate goverance in rapidly emerging non-Western economies (Tsui, Schoonhoven, Meyer, Lau, et al., 2004; Young et al., 2008). This is because the motivations of managers and directors in the West may not hold in the Asian context, and individual directors' motivations to monitor may follow the governance structures that are particular to their context and cultural norms into which they are socialized. Therefore, we believe the Chinese governance and socio-cultural context is both relevant and important to the development of a deeper and more global understanding of directors' identification-monitoring relationships.

Unlike the dispersed equity ownership that is common in corporate America, in most Asian countries, ownership is typically concentrated (Heugens, van Essen, \& van Oosterhout, 2009). Chinese listed firms, for instance, are commonly owned by one dominant shareholder and quite commonly this happens to be the Chinese government itself (Hu et al., 2010; Liu \& Sun, 
2005). This concentrated ownership structure, coupled with the inefficiency associated with state ownership and relatively weak external governance mechanisms, has given rise to a structural conflict of interest between controlling and minority shareholders (Hu et al., 2010; Su et al., 2008). As such, assuring accountabilities and protecting the interests of minority shareholders has become the key focus in China's corporate governance development. For instance, China Securities Regulatory Commission (CSRC) has mandated board independence and oversight as part of its efforts to 'protect the overall interests of the firm, and should be especially concerned with protecting the interests of minority shareholders from being infringed by the controlling shareholder' (CSRC, 2001: Article I.2). ${ }^{1}$ To support the board to perform its governance functions more effectively, directors and senior executives are also required to participate in governance training organized by stock exchanges or their authorized agencies.

Although the monitoring aspect of boards and directors is a clear priority in China's governance development, researchers have thus far paid little attention to directors' monitoring role in the Chinese context. Instead, most existing empirical studies of Chinese companies have focused on the structural dimensions of the board, such as the influence of nominal director 'independence' (e.g., Bai, Liu, Lu, Song, \& Zhang, 2004; Chen, Firth, Gao, \& Rui, 2006; Hu et al., 2010). Past research examining the effects of board structural characteristics on board and firm performance outcomes has produced inconsistent results and as such, has done little in term of increasing understanding of the conduits of board effectiveness (Finkelstein \& Mooney, 2003). Hence, to better understand the determinants of board effectiveness in performing governance tasks, it would appear to be necessary to shift the focus from board structural characteristics to the individual-level attitudinal drivers of directors' task behavior, including monitoring. 
It is tempting to assume, as indeed does much of the international management literature, that the institutional, social, economic and cultural differences been China and the developed Western countries are such that China should be considered a 'limit' comparator - a case so distinct that it is only the points of contrast that are worthy of consideration. In the corporate governance realm, for instance, Miles (2006) argues that China's paternalistic governmental system and hierarchical structure can hinder directors' capability to speak their minds and confront executives. Reinforcing the perspective of Chinese exceptionalism is the suggestion that the outlook and behavior of Chinese organizational stakeholders, from line-employees to directors, is driven by historically-embedded Confucian values, particularly Mianzi. This refers to a socialized preference for maintaining respect within the group and for aversion to losing respect or 'face' amongst peers and superiors (Bond \& Hwang, 1986; Bozionelos \& Wang, 2007). In combination - all else equal - these values are likely to inhibit proactive director monitoring of executive actions and to predispose the individual towards a goal of conflictavoidance. In short, Confucianism would seem to run counter to the Western precept of director responsibility for the proactive surveillance of executive-agents without fear or favor. In culturally stereotypical terms, then, we might expect the monitoring behavior of Chinese directors to be inhibited by the desire to avoid reputational loss.

Yet, here too, the available empirical evidence on Chinese boards is ambiguous, with some reporting strong monitoring effects (e.g., Chen et al., 2006; Kato \& Long, 2006) while others suggest that Chinese directors are ineffective monitors (e.g., Rajagopalan \& Zhang, 2008; Su et al., 2008). Furthermore, Young, Ahlstrom, Bruton and Chan (2001) report that in Chinese firms operating internationally, directors are more active in performing their resource provision role than the monitoring role. Therefore, rather than simply evaluating whether Chinese directors 
are diligent monitors, a more fruitful aim would be to achieve a fine-grained understanding of the individual-level factors that may influence these directors' monitoring engagement.

In sum, while the Chinese corporate and cultural context differs from that in the developed West in some important respects, it cannot be said to be so different as to render comparison inappropriate nor so different as to be incapable of demonstrating relationships of a more general nature. As Li and Nair (2009) point out, some of the corporate governance challenges facing Chinese boards are also typical of other emerging economies. Thus, China provides an appropriate and potentially illuminating context for broadening our understanding of director behavior beyond the developed West and, specifically, to the Asian context (Globerman, Peng, \& Shapiro, 2011; Young et al., 2008).

\section{THEORY AND HYPOTHESIS DEVELOPMENT}

\section{Director Organizational Identification, Executive-Agent Identification and Monitoring}

Drawing on social identity theory, the strength and foci of directors' social identifications can influence monitoring in different ways (Ashforth \& Mael, 1989; Golden-Biddle \& Rao, 1997; Hillman et al, 2008; van Knippenberg, 2000). Hillman and others (2008) argue that director identifications influence director monitoring via internalized role expectations. Building on these arguments, we propose that directors with stronger identifications with the organization will contribute more diligently to monitoring than will directors with stronger identifications with executive-agents. This is because each type of director identification gives rise to different expectations in regard to monitoring. Research has shown that individuals who identify strongly with the organization are more likely to perform their roles with high levels of effort, persistence, and task mastery (Riketta, 2005). The more strongly individuals identify with the organization, the more likely they are to invest effort in both in-role and extra-role tasks and thus be more 
proficient in what they do overall because doing so serves the interests of the organization (Ashforth \& Mael, 1989; van Knippenberg, 2000). When applied to board directors, individuals with a stronger identification with the organization are likely to contribute more strongly to monitoring because doing so is seen as serving the interests of the organization as well as meeting their fiduciary responsibilities (Bainbridge, 2003; Golden-Biddle \& Rao, 1997). This line of argument would also seem to apply well to the Chinese context, where the corporate governance system emphasizes the protection of the organization's interests as a first priority of the board (Company Law, 2006; OECD, 2011). Thus, on this basis, we would expect that Chinese directors with a strong organizational identification would prioritize and actively engage in monitoring.

The motivation to monitor actively is arguably less pronounced for those directors with a stronger identification with executive-agents. Consistent with both agency theory and the managerial power perspective, these directors are likely to be less inclined to monitor actively because monitoring is assumed to be inconsistent with the role expectations and behavioral norms of the top management echelon (see Golden-Biddle \& Rao, 1997). From this identity perspective, active monitoring both reduces the discretion of executive-agents to manage the organization and also runs the risk of damaging trust between directors and executive-agents (Golden-Biddle \& Rao, 1997). Extant research and theory, particularly that associated with managerial power theory, suggests that having a stronger identification with top managers may serve to attenuate directors' monitoring behavior. For instance, managerial power theory assumes that board members who identify with the Chief Executive Officer (CEO), or who are influenced or 'captured' by the CEO, or have close ties with top management, are necessarily motivated to reduce monitoring (Finkelstein \& Hambrick, 1996). Moreover, studies of Chinese 
firms show that Confucian values, including cohort loyalty, paternalism, and reciprocity, remain a prevalent influence (Cheung \& Chan, 2008; Hofstede, van Deusen, Mueller, \& Charles, 2002), which may further weaken directors' monitoring activity if they identify strongly with the firm's top executives.

However, we do not rule out the possibility that directors with a stronger identification with executive-agents do undertake some monitoring, since monitoring is, after all, a core governance role of directors, irrespective of context. Even directors who strongly identify with being a top manager may still engage in some monitoring as a way to exhibit diligence and attentiveness without appearing antagonistic to top management. This supposition represents an important qualification to extant theories on boards, particularly managerial power theory, which assumes that identification with top management necessarily suppresses monitoring behavior (Bebchuk \& Fried, 2004; Golden-Biddle \& Rao, 1997). Directors identifying strongly with executives may still demonstrate monitoring behavior but will do so to a lesser extent than directors with a stronger organizational identification. As such, we hypothesize the following relative effect:

Hypothesis 1: Director identification with the organization will have a stronger positive effect on monitoring than will director identification with executive-agents.

\section{The Mediating Role of Director Learning Goal Orientation}

According to goal orientation theory, an individual with high learning goal orientation is motivated primarily by the desire to maximize role proficiency by seeking out and acting on developmental feedback in order to acquire additional knowledge and skills (Vandewall, 1997, 2001). Rather than being demotivated by obstacles, setbacks or negative feedback, such 
individuals strive to capitalize on these into positive learning experiences. They are more likely to acknowledge their own errors and failures and see mistakes as opportunities to improve rather than badges of dishonor. Individuals with a stronger learning goal orientation view success and failure in their role as being dependent on high levels of effort, perseverance, attention to detail and initiative (Button et al., 1996; Dweck, 1999). Research in various contexts has shown that individuals with stronger learning goal orientation invest more effort in strengthening their role capabilities and engage in higher levels of in-role task performance (Chughtai \& Buckley, 2010; Kaplan \& Maehr, 2007; Vandewalle, 1997, 2001). Also, having a high learning goal orientation has been found to be associated with more in-depth processing of information (Greene \& Miller, 1996). By extension, directors with strong learning goal orientation are likely to set more challenging goals for themselves and to have higher expectations regarding engagement in monitoring. They are less likely to want to conceal their own errors and more likely to seek feedback from others, including fellow directors, executive-agents, owners, employees and customers.

We believe there are strong reasons for exploring director learning goal orientation as one potential mechanism mediating the relationship between director social identifications and their engagement in monitoring. In particular, the literature on social identity orientations assumes that such identifications can shape behavior through different motivational mechanisms (Brewer \& Gardner, 1996; Brickson, 2000; Hillman et al., 2008; Golden-Biddle \& Rao, 1997; Oyserman, 2007; Westphal \& Zajac, 1997). Hillman and others (2008) suggest that the link between social identification and behavior may be mediated by mechanisms such as role expectations, feelings of obligation, and sympathy. For instance, according to Oyserman (2007), motivation is identitybased, contextually cued and subject to behavioral self-regulation in pursuit of identity-shaped 
goals: 'Not only is motivation identity based, but success at pursuing a goal feels good because it reinforces the identity in which it is based' (2007: 432, 443). Similarly, Meyer and others (2004) propose that goal regulation that 'reflect[s] the reasons for, and purpose of a course of action being contemplated or in progress' (2004: 998), may mediate the relationship between organizational identification and task performance, and that goal orientations are an important aspect of goal regulation. For these reasons, we suggest that a clearer understanding of the relationship between director organizational identification and monitoring, and executive-agent identification and monitoring, may be achieved by considering the role of director learning goal orientation as a potential mediating mechanism.

It is important to acknowledge, however, that there is variation in the conceptualization of learning goal orientation in the literature. On the one hand, there is literature that treats learning goal orientations as an individual trait or disposition (Kaplan \& Maehr, 2007; Payne, Youngcourt, \& Beaubien, 2007). On the other hand, there are studies that consider learning goal orientation as a situationally-determined state and domain-specific variable induced by salient features of a situation (Chughtai \& Buckley, 2010; DeShon \& Gillespie, 2005 ; Vandewalle, 2001). We take the latter approach because we contend that director orientation to task learning and task mastery is, by definition, highly situationally-determined rather than dispositional and trait-like. Whether or not an individual exhibits high learning goal orientation in a particular role depends not on some superordinate motivational predisposition but, rather, on the nature of that role, the meanings and identifications they attribute to that role, and how these attributions, in turn, shape their goal orientation.

Having a strong identification with the organization is more likely to cause directors to approach their key tasks, including monitoring, with a strong orientation towards continuous 
personal learning and improvement so as to maximize their contribution to the success of the organization. Whilst we believe ours to be the first study to test this proposition in the corporate governance domain, research in other contexts lends support to our position. For instance, using data from a sample of Pakistani high school teachers, Chughtai and Buckley (2010) report that organizational identification relates strongly and positively to high learning goal orientation which, in turn, increases feedback seeking, error communication and job performance.

However, we further propose that a learning goal orientation can also mediate the relationship between a director's identification with executives and his/her level of executive monitoring. Having a stronger executive identification can strengthen monitoring activity by positively impacting a director's learning goal orientation. There is no intuitive reason why a director, who identifies strongly with executives (perhaps because they themselves also hold executive positions on one or more boards) should necessarily be predisposed against wanting to strengthen their capacity to be better at their job by leveraging their learning on the job. Indeed, Gong, Huang, and Farh's (2009) study of Taiwanese employees found that learning goal orientation motivated employees to become more committed and creative in their work and subsequently achieved higher levels of job performance. By the same token, without director learning goal orientation as a mediating mechanism, stronger executive-agent identification may not necessarily translate into higher monitoring.

As such, in addition to expecting both organizational identification and executive-agent identification to directly influence monitoring, for both of these identifications we also expect a partial mediated effect of director learning goal orientation. Accordingly, we hypothesize as follows: 
Hypothesis 2: Director learning goal orientation will mediate the effects of director identification with the organization, and director identification with executive-agents, on monitoring.

We further propose, though, that the mediated effect of director identification with the organization on monitoring will be stronger than the mediated indirect effect of executive-agent identification on monitoring. As mentioned above, different director social identifications may prescribe different role expectations for directors when it comes to monitoring. Having a stronger identification with the organization is likely to lead to a higher level of learning goal orientation, which precipitates higher levels of monitoring than would having a stronger identification with executives. This is because a stronger organizational identification carries stronger expectations to be highly proficient across all director governance tasks, including both monitoring and resource provision, in the service of the organization (Hillman et al., 2008). The motivation to be effective in all key tasks is reflected in a high level of learning goal orientation which, in turn, promotes greater attention to monitoring executives via direct observation, gathering and interrogating information, and interpreting and anticipating executive behavior. At the same time, we propose that the mediated indirect effect on monitoring will be weaker for directors with stronger executive-agent identification compared to directors with a stronger identification with the organization. Based on the logic of agency theory and managerial power theory, we suggest that the motivation to be a diligent monitor is less pronounced for directors with stronger executive-agent identification. Thus, we hypothesize as follows:

Hypothesis 3: The mediated indirect effect of director identification with the organization on monitoring will be stronger than the mediated indirect effect of director identification with executive-agent. 


\section{The Moderating Role of Director Avoidance Orientation}

Although the relationships between director identifications and monitoring may be mediated by director learning goal orientations, we also recognize that the strength of these mediated relationships may be conditional on other factors. Such factors may range from individual traits and behavioral predispositions to situational factors external to the role itself, including sociocultural norms and institutional-regulatory practices and pressures. By virtue of their nature, socio-cultural norms may also predispose the individual director to certain modes of selfregulation; that is, to either pursue or avoid certain anticipated outcomes on the basis of norms into which the individual has been socialized. In the Chinese socio-cultural context, we propose that one dispositional characteristic, namely the level of director avoidance orientation, may be particularly salient.

Avoidance orientation refers to a focus on avoiding failure (Kaplan \& Maehr, 2007: 144). From this perspective, avoidance orientation involves placing a high level of importance on managing the impressions others have of your ability (Kaplan \& Maehr, 2007). Research has shown that having a high avoidance orientation is associated with reduced effort, procrastination, and low task engagement, shallow processing of information and a general tendency to withdraw or inhibit responding (Elliot, 1999; Elliot \& McGregor, 1999). Whereas learning goal orientation is a task-related motivational state, avoidance orientation is a trait-like dispositional characteristic related to self-regulation. As such, since these two orientations have different antecedents, the two are not necessarily mutually exclusive. Having a high avoidance orientation does not necessarily preclude a director from having a learning goal orientation since the desire to avoid appearing incompetence can also induce a motivation to develop the capabilities 
necessary for task effectiveness. Accordingly, both avoidance orientation and learning goal orientation may be concurrent and congruent forms for motivation (Elliot, 1999: 174). Equally, it is possible that the two may interact negatively, with the disposition to avoidance possibly serving to inhibit the situationally-influenced motivation to learn.

Avoidance orientation is a construct that is highly relevant in the Chinese context, where the inhibitive effects of avoidance orientation may reflect the Confucian cultural value of Mianzi (i.e., preservation of 'face' or reputation). This value informs a strong behavioral norm to avoid questioning the ideas or opinions of others and risking exposure to receiving negative feedback from others, particularly those within a work group, such as a board of directors (Wang, Wang, Ruona, \& Rojewski, 2005).

We have proposed above that having stronger identifications, particularly identification with the organization, arouses motivation to be highly competent and diligence in the domain of monitoring. Drawing on the literature on avoidance orientation, and acknowledging the possibility that Mianzi may be a highly relevant behavioral antecedent in the Chinese context, we further propose that the effects of identification on learning goal orientation and, in turn, on monitoring will be weaker under conditions where directors have a high avoidance orientation. In other words, a director's avoidance orientation stands to weaken the indirect effects of identification on monitoring via learning goal orientation. Because of their goal to maintain competency in the eyes of peers and to avoid negative appraisals and feedback, it is probable that directors predisposed towards avoidance will be less actively engaged in the risky task of monitoring (see Harackiewicz et al., 1998). By extension, we suggest that the effect of high avoidance orientation as a negative moderator applies irrespective of the individual's particular identification focus; that is, avoidance orientation should be understood as being an independent 
moderator of the identification-goal orientation-monitoring relationship rather than as an additional mediator of that relationship. It may be the case that avoidance orientation negatively moderates the influence of director identification on learning goal orientation; alternatively it is possible that its influence if chiefly to weaken the influence of learning goal orientation on monitoring activity. Exactly where in the relationship the moderation occurs is, we suggest, a matter for empirical investigation rather than a priori deduction and, as reported below, our findings in this respect are particularly illuminating.

We thus argue that avoidance orientation weakens the indirect effects of identity on monitoring. As levels of avoidance orientation increase, the positive effects of identification on learning goal orientation and, in turn, on monitoring are weakened. Accordingly:

Hypothesis 4a: The effect of director identification with the organization on monitoring via learning goal orientation is moderated by director avoidance orientation, such that the indirect effect will be weaker under high avoidance orientation than under low avoidance orientation.

Hypothesis 4b: The effect of director identification with executive-agents on monitoring via learning goal orientation will be moderated by director avoidance orientation, such that the indirect effect will be weaker under high avoidance orientation than under low avoidance orientation.

\section{METHOD}

\section{Sample and Data Collection}


Our sampling frame included 4,811 directors of the top 500 publicly listed companies in China ranked by total assets as reported in their 2010 annual reports. A total of 2086 directors were identified and contacted. Directors with multiple directorships were asked to focus their responses on the board where they had served the longest period of time. We collected data in two surveys administered eight weeks apart. Director identifications, learning goal orientation, avoidance orientation, and control variables were included in the first administration and director engagement in monitoring in the second administration. Two rounds of reminders were also sent at four and eight weeks after. Our questionnaires were designed in English and translated into Chinese by two bilingual academics with expertise in corporate governance. The Chinese version was then translated back to English by two PhD students native in Chinese. The reversetranslated version remained largely consistent with the original version. The questionnaire was then pre-tested by 15 EMBA students in China to ensure the meanings of the questions were easily understandable by Chinese directors.

The difficulties attendant to collecting multiple source data from the corporate elite are well acknowledged (Huse, 2007). We took several steps to reduce common method bias following the procedural remedies suggested by Podsakoff and others (Podsakoff, MacKenzie, \& Podsakoff, 2003; Podsakoff, MacKenzie, \& Podsakoff, 2012). These included a temporal separation (eight-week time gap) in our survey, and the proximal separation between our key constructs by inserting questions of theoretically unrelated constructs such as organizational selfesteem and board cultural norms, as well as demographic questions. Directors were also asked to provide a unique identifier (i.e., last six digit of mobile phone number) on both parts of the survey so that the researchers could match the parts without revealing the identity of the respondents. To reduce and control for social desirability bias, we assured respondents that the 
survey was strictly confidential and we also included Strahan and Gerbasi's (1972) short (tenitem) version of the Marlowe-Crowne social desirability scale in the part-two questionnaire.

In total, 300 directors responded to both parts of the survey, resulting in a 14.4 per cent response rate, which is comparable to the response rates of executive surveys in prior studies in the emerging economy context (Kriauciunas, Parmigiani, \& Rivera-Santos, 2011). Respondent descriptions are summarized in Table 1. We tested for potential non-response bias using demographic information available from annual reports. We focused on demographic variables such as education level, age, years of director experience, director tenure in the focal company, and functional background. No systematic difference was found between respondents and nonrespondents. We thus concluded that non-response bias was not evident in our data.

Insert Table 1 about here

\section{Measures}

The key variables in our model are latent constructs, and accordingly we used adapted survey scales to measure these variables. Table 2 presents the items and convergence validity of the measurement scales. We used Hancock and Mueller's (2001) maximized reliability coefficient H to assess construct reliability, because Cronbach's alpha and related reliability measures are limited to assessing composite scales formed from a construct's indicators, rather than assessing the reliability of the latent construct itself as reflected by its indicators (Hancock \& Mueller, 2001).

Insert Table 2 about here 
Organizational identification. Organization identification was measured by means of the social identification scales developed by Mael and Ashforth (1992) and adapted by McDonald and Westphal (2010).

Executive-agent identification. Executive-agent identification was also measured using the social identification scales developed by Mael and Ashforth (1992) and adapted by McDonald and Westphal (2010). Both identification scales have not been validated in an emerging economy context (in particular that of China), we conducted a confirmatory factor analysis (CFA) for the purpose of scale purification. The item that links personal successes with the successes of the identity foci (e.g. 'the successes of this company are my successes') had low item-to-construct correlation and variance explained less than 0.25 , which is possibly due to the semantic property of this item leading to culturally induced method bias that override construct meaning. We removed this item as it stood to compromise the face and discriminant validity of the scale. The remaining items loaded cleanly on two factors corresponding to organizational identification and executive-agent identification, each with five indicator items. Both scales had satisfactory convergent validity evidenced by high coefficient Hs of 0.87 and 0.83 , respectively.

Learning goal orientation. We adapted goal orientation scales developed by Vandewalle (1997) to measure directors' (situational) learning goal orientation.

Avoidance Orientation. We also used a scale developed by Vandewalle (1997) to measure avoidance orientation. Both orientation scales were originally designed for the general work domain and were validated using university student samples. We adapted the items to fit the specific work domain of company directors and conducted CFA to remove items with low variance explained by the corresponding factor $\left(R^{2}<0.25\right)$. The finalized scale for learning goal orientation included three items loaded cleanly on a single factor, with a reliability coefficient $\mathrm{H}$ 
of 0.81. For avoidance orientation, the original Vandewalle (1997) four-item scale was supported by the CFA, where the four items loaded on a single factor with a reliability coefficient $\mathrm{H}$ of 0.78 .

Monitoring Role. Our dependent variables are individual directors' level of engagement in the monitoring. Prior studies of board functions have developed scales to measure directors' monitoring behavior at the board level (Huse, 2007; McDonald, Khanna, \& Westphal, 2008). We adapted the items of the established scale to the individual level and evaluated the internal consistency validity through CFA. After removing invalid items $\left(R^{2}<0.25\right)$, the final scale included three items with a reliability coefficient $\mathrm{H}$ of 0.92 . The final items for our key variables are included in Table 2.

Control variables. We also included several control variables that may influence direct role engagement. Studies suggest that multiple directorships lead to competing demand on directors' attention while also increasing director's strategic resources (Ferris, Jagannathan, \& Pritchard, 2003). We controlled for multiple directorships using a count variable reflecting the number of boards the director currently serves on. Renewal of directorships may also influence director engagement in monitoring. The closer a director is to the end of their tenure, the more incentive they may have to perform their roles diligently to achieve successful tenure renewal. We controlled for this effect using the number of months remaining in the current director tenure. The structural research on boards has also focused on director independence as an antecedent of board function (Hu et al., 2010; Peng, 2004). We used a dummy variable to differentiate independent directors from executive and non-executive directors in our analysis. In addition, we also controlled for social desirability bias using Strahan and Gerbasi's (1972) shorter version of the Marlowe-Crowne social desirability scale for model robustness test. Table 
3 below shows the descriptive statistics and correlations of all variables. It is important to note that the social desirability score did not show significant correlation with our key theoretical constructs. This preliminary evidence suggests that our survey items did not solicit significant social desirability bias.

Insert Table 3 about here

\section{Analytical Procedures}

Structural equation modeling (SEM) is used in data analysis (Williams et al., 2009). Anderson and Gerbing's (1988) comprehensive two-stage SEM analytical procedure was followed in the data analysis. In the first stage, we performed a CFA on the measurement model. In this stage the goodness-of-fit of the original measurement model was compared with nested models to assess the discriminant validity of the constructs. In the second stage, we tested structural models for hypotheses testing. For all aspects of our SEM analyses, we assessed and reported multiple model fit indicators as suggested by $\mathrm{Hu}$ and Bentler (1999).

\section{ANALYSES AND RESULTS}

\section{Measurement Model and Construct Validity}

The measurement model included the latent constructs and their corresponding measurement items as specified in Table 2. The model test is essentially a CFA procedure. As reported in Table 2, the constructs all showed good convergence validity evidenced by high Hs, all above 0.70. Overall, the model had adequate fit. The CFI (0.955) and TLI (0.952) were both above the 0.95 threshold. The RMSEA (0.047), SRMR (0.048), and $\chi^{2}$ ratio (1.72) were also all in the desired ranges. Overall, the measurement model showed satisfactory fit. 
Following Anderson and Gerbing (1988), we conducted chi-square difference tests on the original measurement model and several nested models to assess the discriminant validity of the constructs. In each nested model we imposed constraint between a pair of conceptually separate constructs by setting their correlation to one. The $\chi^{2}$ difference tests returned significant results, suggesting that the nested (pair-wise constrained) models were significantly inferior to the original model. In conclusion, we found that converging the constructs resulted in significant deterioration of model fit, providing evidence of the discriminant validity of the construct specification of our original measurement model. ${ }^{2}$

\section{Hypotheses Testing}

Hypothesis 1 compares the relative effects of two director identifications on the level of monitoring performed by directors. We used a structural model to test the total effects of organizational and executive-agent identifications on monitoring, after controlling for observed structural variables (independence dummy, tenure, and multiple directorship) and social desirability index. We then followed the procedure by Steiger (1980) and Cohen and Cohen (1983, pp. 56-57) to compare the strength of the effects.

The model fitted the data well, evidenced by a $\chi^{2}$ ratio of 1.89 , a CFI of 0.952 , and a SRMR of 0.055 . Organizational identification had a positive effect on the level of monitoring behavior, $\beta=0.56(\mathrm{p}<.001)$. Executive-agent identification also had a positive effect albeit with a magnitude, $\beta=0.23(\mathrm{p}<.01){ }^{3}$ To test whether these effects are statistically different, we performed Steiger's z-test (see Steiger, 1980). In this test, the partial correlations between the two identification variables and the dependent variable (monitoring) were compared after removing the effects of the control variables. The comparison result $(z=5.00, p<.001)$ suggests 
that while both organizational and executive-agent identification have positive effects on monitoring, organizational identification has the stronger effect of the two. Therefore, we found support for hypothesis 1.

Hypotheses 2 and 3 focus on the mediating effect of learning goal orientation between director social identifications and monitoring. We first followed MacKinnon et al.'s (2002) joint significance test principle to test the moderation effect; and then complemented this approach by using a bootstrap test of the mediated indirect effect using SEM (Bollen \& Stine, 1990; Shrout \& Bolger, 2002).

MacKinnon et al. (2002) suggest that the test of the joint significance of the two effects comprising the mediation effect offers the best balance of Type I error and statistical power across all mediation analysis approaches. This recommended approach tests the null hypothesis that mediated indirect effect equals zero by testing that both paths from independent variable to mediator and from mediator to dependent variable are zero. To test these paths simultaneously, we estimated a structural equation model that mirrors our theoretical model. The results of this model are reported in Figure 1. The model achieved satisfactory model fit evidenced by its CFI (0.954), SRMR (0.053), and $\chi^{2}$ ratio (1.75). As shown in Figure 1, all paths comprising the mediation relationship were positive and significant. Specifically, organizational identification positively affected learning goal orientation $(\beta=0.54, \mathrm{p}<.001)$. Executive-agent identification also positively affected learning goal orientation $(\beta=0.26, p<.01)$. Finally, the effect of learning goal orientation on monitoring was also positive $(\beta=0.73, p<.01)$. It is also worth noting that once the effect of learning goal orientation was controlled for, the direct effects of organizational identification $(\beta=0.17, p=0.348)$ and executive-agent identification $(\beta=0.031$, 
$p=0.792$ ) became non-significant. We found that the identification effects on monitoring were fully mediated by director's learning goal orientation.

Insert Figure 1 about here

Although the above joint significance test approach is generally sufficient in detecting mediating effect, researchers have strongly urged that this test should be used in conjunction with other tests (Fritz \& MacKinnon, 2007; Fritz, Taylor, \& MacKinnon, 2012). Accordingly, in the second step, we used a bootstrapping approach to test the mediated indirect effect (Bollen \& Stine, 1990; Shrout \& Bolger, 2002). Bootstrapping is a non-parametric method based on resampling with replacement which is done many times (e.g., 1000 times). From each of these samples the indirect effect is computed and a sampling distribution can be empirically generated. A confidence interval is computed and it is checked to determine if zero is in the interval. If zero is not in the interval, then the researcher can be confident that the mediated indirect effect is statistically significant. The results of our bootstrapping analysis showed positive indirect effects of both organizational identification $(\beta=0.25, \mathrm{p}<.05)$ and executive-agent identification $(\beta=$ $0.12, \mathrm{p}<.05)$ on monitoring, mediated by learning goal orientation. ${ }^{3}$ Therefore, we found a consistent mediating effect of learning goal orientation, thus supporting hypothesis 2 .

To test hypothesis 3 , we compared the sizes of the mediated indirect effects of organizational and executive-agent identifications. Two statistical evidences were used for this comparison. First, the bootstrapping results in the previous step suggested that, from 1000 iterations, the average indirect effect of organizational identification $(0.25)$ is more than double the indirect effect of executive-agent identification (0.12). Expanding the bootstrapping iteration number of 2000 returned identical results. Secondly, the paths from two identifications to the 
mediator contribute to the differential indirect effects. The path coefficients were compared using Steiger's (1980) $z$ test, similar with the test of hypothesis 1 . The test returned a $z$ score of $4.48(\mathrm{p}<.001)$, suggesting that the path coefficients were significantly different. Drawing on both the bootstrapped indirect effects and the Steiger's test of path coefficient difference, we found consistent evidence that the mediated indirect effect of organizational identification was stronger than that of executive-agent identification, thus supporting hypothesis 3.

Hypotheses $4 \mathrm{a}$ and $4 \mathrm{~b}$ state that the indirect effects of identifications on monitoring via learning goal orientation are moderated by director's avoidance orientation. In other words, the mediated indirect effects are conditional on the level of avoidance orientation. Following prior studies, we tested these conditional indirect effects using moderated-mediation analytical procedure (e.g. Ng, Ang, \& Chan, 2008; Preacher, Rucker, \& Hayes, 2007). To support a conditional indirect effect, four conditions must be met: (1) the independent variable significantly predicts the mediator; (2) there is a significant interaction between the independent variable and the moderator in predicting the mediator (i.e., Preacher et al.'s (2007) model 2), and/or there is a significant interaction between the mediator and the moderator in predicting the dependent variable (i.e., Preacher et al.'s (2007) model 3); (3) the mediator significantly predicts the dependent variable; and (4) there is different conditional indirect effect of the independent variable on the dependent variable, via the mediator, across low and high levels of the moderator. Conditions 1 and 3 were supported from previous test of the mediating hypotheses (see Figure 1). To assess condition 2, we ran SEM analyses with a latent variable interaction using the numerical integration function of Mplus 4. Following $\mathrm{Ng}$ et al. (2008), we included the interaction of the moderation with the independent variables and the mediator in separate models. The results of these models are summarized in Table 4. 
Insert Table 4 about here

As shown in the results of model 1, the interaction of organizational identification with avoidance orientation had a negative effect on learning goal orientation $(\beta=-0.37, p<0.01)$. In model 2, the interaction of executive-agent identification with avoidance orientation also had a negative effect on learning goal orientation $(\beta=-0.36, p<0.01)$. In model 3 , the interaction of avoidance orientation and learning goal orientation was non-significant $(\mathrm{p}>.1)$. These results suggest that the moderating effect of avoidance orientation occurs in the first stage of the mediated indirect effect, namely, the linkage between identifications and learning goal orientation. Once learning goal orientation is induced by identification, its effect on monitoring behavior is no longer conditional on avoidance orientation. We therefore found support to condition 2.

To assess condition 4, we used a bootstrapped approach to test the indirect effects (Bollen \& Stine, 1990; Shrout \& Bolger, 2002), while setting the moderator at high (mean plus one standard deviation) and low (mean minus one standard deviation) conditions. We did this for both indirect effects (see Table 5).

Insert Table 5 about here

As shown in Table 5, when avoidance orientation is at a high level, both indirect effects were non-significant, while they remained positive within $95 \%$ confidence interval (i.e. significant at $\mathrm{p}<0.05)$ when avoidance orientation is at a low level. Accordingly, there is a significant difference in the conditional indirect effect across different levels of the moderator. 
Specifically, both indirect effects are stronger when avoidance orientation is at a low level than at a high level. We thus found support for condition 4. Altogether, all four conditions to support a conditional indirect effect were met, and therefore our hypotheses $4 \mathrm{a}$ and $4 \mathrm{~b}$ were supported. Figure 2 summarizes our results and the conditional indirect effects of director identifications on monitoring via learning goal orientation.

Insert Figure 2 about here

\section{DISCUSSION}

What underlying factors affect individual directors' engagement in monitoring role in emerging economy such as China? To address this question, this study examined the indirect effects of directors' identification (with the organization and with executive-agents) on their monitoring behavior via directors' learning goal orientation, in addition to the moderating role of director avoidance in these mediated relationships.

Our results show that directors with a stronger organizational identification are more willing to engage in monitoring. This finding accords with the emphasis in the Chinese context on loyalty to the firm and commitment to its long-term development (Miles, 2006). Our results also confirm the importance of learning goal orientation as a mediating mechanism, particularly in transmitting organizational identification into monitoring behavior. Further, given the salience of the Confucian value of Mianzi in Chinese culture, we found that avoidance orientation as an individual-level dispositional characteristic negatively moderates the mediating effect of directors' learning goal orientation on their identification and monitoring, with the locus of moderation being the association between identification and goal orientation. For our sample of Chinese directors, while learning goal orientation strengthens monitoring activity, avoidance 
orientation inhibits learning goal orientation regardless of the director's identity position. This finding highlights the importance of developing a governance model that incorporates culturallyinformed personal dispositions to enrich the understanding of board governance, especially in an emerging corporate governance context.

\section{Contribution to Corporate Governance Theory and Knowledge}

Our study makes several important contributions to the corporate governance literature. Recent research on directors' governance behavior suggests that directors' social identities are necessary antecedents to shaping their monitoring and resource behaviors (see Hillman et al., 2008; McDonald \& Westphal, 2010; Westphal \& Zajac, 1997). Our study contributes to a better understanding of the director identification-monitoring relationships by integrating social identity theory and goal orientation theory. Accordingly, we show that learning goal orientation and avoidance orientation play important intervening roles in the association between directors' social identity and their monitoring activity. Using this social identity-based behavioral approach, the study contributes to a more nuanced examination of different forms of engagement in monitoring and of the various motivational factors that prefigure the direction, intensity and duration of monitoring behavior.

Our findings regarding avoidance orientation highlight the need to take account of the potential moderating influence of dispositional characteristics on the strength of situationallyinduced learning goal orientation and, in turn, on monitoring behavior. This is particularly so in a cultural context such as that of China, where our results show that high avoidance orientation does diminish the motivational mechanisms arising from high director identification with either the organization or its executives. Culture matters, but so too does the extent to which individual 
directors have internalized particular cultural values - and this cannot be assumed. Thus, rather than accepting simple stereotypes of Chinese directors as either 'good' or 'bad' monitors, or as inherently avoidance-prone by socialization, it is more meaningful to examine, firstly, the nature and strength of director social identifications, secondly, the nature and extend of role-related goal orientation, and, thirdly, the degree to which individual directors do demonstrate socialized cultural dispositions and the nature, locus and degree of influence of such dispositions.

Finally, this study also makes an important empirical contribution to widening the domain of research on the well-springs of director behavior beyond a developed, Western context by examining director behavior in an emerging economy context, namely that of the Peoples' Republic of China. While our directors' identification-to-behavior framework derives from prior theory and research grounded in an Anglo-American context (e.g., Golden-Biddle \& Rao, 1997; Hillman et al., 2008; Withers, Corley, \& Hillman, 2012), our study also extends existing understandings conceptually, empirically and spatially. We incorporate insights from educational psychology (i.e., director orientations) into the framework to not only extend the understanding of this line of research, but also better examine some of the motivational aspects of Chinese directors. This approach enables us to highlight the importance of the national context for the study of the cognitions and motivations of individual directors, which we believe helps advance the theory building of director behavior to a broader context. Empirically, prior research on Chinese boards has focused predominantly on structural dimensions of boards and directors, with inconclusive findings on their governance efficiency. Our findings on Chinese directors indicates the importance of seeing director effectiveness in emerging contexts as being contingent on individual-level social identification, goal orientation and dispositional characteristics - and not predestined. Therefore, the study provides new insights into the 
corporate governance research of Chinese firms by strengthening a contextually-aware behavioral perspective on governance effectiveness (Hillman, et al., 2008; van Essen et al., 2012; Young et al., 2008).

\section{Implications for Practice}

Various governance stakeholders, including regulators, shareholder bodies and the business media, have placed a great deal of emphasis on the monitoring aspect of directors' governance responsibilities - and China is no different. Our findings are useful in providing practical suggestions to boards on selecting and developing directors with greatest potential to contribute to the overall efficiency of the board as a whole. First, there are implications relating to director selection. Most importantly, knowing that directors with stronger identifications with the organization, lower avoidance orientation and higher learning goal orientation can positively impact engagement in monitoring should be an important consideration in director selection. Second, there are implications for director development. Although different types of social identifications (i.e., organizational and executive-agent identifications) can lead to different levels of monitoring engagement, our study shows that director orientations are also important factors to influence directors' monitoring behavior. This has clear implications for the content and significance of director training and development initiatives. Accordingly, we suggest that if

firms can develop director selection and development programs that incorporate both the identifications and orientations of directors, it may enhance the board's overall engagement with and effectiveness in monitoring.

\section{Limitations and Future Research}


Whilst our study is the first to test relationships among director social identifications, learning goal orientation, avoidance orientation, and director monitoring, like any such study it is not without limitations. First, although we have used a time-lagged mechanism in our survey data collection, we acknowledge the cross-sectional design as one such limitation. We collected data on directors' identification, goal orientation and engagement in monitoring at a single point in time. It is possible that director behaviors at one time may reinforce or alter their social identifications and learning goal orientation at a later time. Future research is needed which uses a longitudinal design to examine the dynamic and evolutionary process of the director identification-to-behavior linkage. Another limitation of our study is that it was conducted at an individual level. A firm's corporate governance structure is multi-level (organizational, shareholder, board and individual) (Boyd, Haynes, \& Zona, 2011; Dalton \& Dalton, 2011) and a country's corporate governance development is a result of macro- and micro- and external and internal governance mechanisms (Filatotchev \& Nakajima, 2010; Shleifer \& Vishny, 1997). Given this, we recognize the importance of individual, board, organizational and institutional characteristics in predicting directors' engagement in monitoring. Accordingly future research could build on our study by examining the impacts of director social identifications within a multi-level framework. It may also be fruitful for work to consider the moderating role of board social and human capital since Haynes and Hillman (2010) show that board capital can impact board decision-making. It may also be worthwhile for future research to consider factors than shape director social identifications which could have particular practical relevance to director selection processes. Although this study is among the few to have examined the behavioral predictors of directors in China, we believe further research in needed to explore these relationships in other institutional contexts, especially in emerging economies, to enhance further 
our understanding of the governance behavior of corporate directors globally. Equally, our findings alert researchers working in developed corporate governance contexts to the worth of considering a wider range of dispositional characteristics, including avoidance orientation, in future studies. Lastly, while directors' monitoring function is the focus of this study, resource provision is another key governance role of directors that is worthy of further exploration in future research. 


\section{NOTES}

1. At present, a board consisting of a minimum of one-third of independent directors is mandated by CSRC (2001).

2. Since our study is the first to apply the identification scales in an emerging context, we also assessed their criterion validities. Hillman et al. (2008) propose that organizational identification of a direct will incur high level of monitoring behavior, while executive-agent identification of a direct will promote resource provision. After controlling for director tenure (month), director type (independence dummy), experience with the firm (month), experience as a director (month), multiple directorship, and social desirability, we found that organizational identification positively predicts monitoring $(b=0.704, p=0.000)$, and executive-agent identification positively predicts resource provision $(b=0.326, p=0.000)$. Thus we found evidence for criterion validities of the two identification scales.

3. Full results available upon request. 


\section{REFERENCES}

Anderson, J. C. \& Gerbing, D. W. 1988. Structural equation modeling in practice: A review and recommended two-step approach. Psychological Bulletin, 103: 411-423.

Ashforth, B. E. \& Mael, F. 1989. Social identity theory and the organization. Academy of Management Review, 14(1): 20-39.

Bai, C., Liu, Q., Lu, J., Song, F. M., \& Zhang, J. 2004. Corporate governance and market valuation in China. Journal of Comparative Economics, 32(4): 599-616.

Bainbridge, S. M. 2003. Director primacy: The means and ends of corporate governance. Northwestern University Law Review, 97(2): 547-607.

Bebchuk, L. \& Fried, J. 2004. Pay without performance: The unfulfilled promise of executive compensation. Cambridge, M.A.: Harvard University Press.

Bollen, K. \& Stine, R. 1990. Direct and indirect effects: Classical and bootstrap estimates of variability. Sociological Methodology, 20: 115-140.

Bond, H.M. \& Hwang, K.K. 1986. The social psychology of Chinese people. In H.M. Bond (Ed.) The Psychology of the Chinese People. New York: Oxford University Press: 213-66.

Bozionelos, N. \& Wang, Li. 2007.An investigation on the attitudes of Chinese workers towards individually based performance-related reward systems. International Journal of Human Resource Management, 18(2): 284-302

Boyd, B. K., Haynes, K. T. \& Zona, F. 2011. Dimensions of CEO-board relations. Journal of Management Studies, 48(8): 1892-1923.

Brewer, M. B. \& Gardner, W. 1996. Who is this 'we'?: Levels of collective identity and selfrepresentations. Journal of Personality and Social Psychology, 71(1): 83-93.

Brickson, S. L. 2000. The impact of identity orientation on individual and organizational outcomes in demographically diverse settings. Academy of Management Review, 25(1): 82-101.

Brickson, S. L. 2007. Organizational identity orientation: The genesis of the roel of the firm and distinct forms of social value. Academy of Management Review, 32(3): 864-888.

Button, S. B., Mathieu, J. E. \& Zajac, D. M. 1996. Goal orientation in organizational research: A conceptual and empirical foundation. Organizational Behavior and Human Decision Processes, 67(1): 26-48.

Capezio, A., Shields, J. S. \& O’Donnell, M. 2011. Too good to be true? Board structural independence as a moderator of CEO pay-for-performance. Journal of Management Studies, 48(3): 487-513.

Chen, G., Firth, M., Gao, D. N., \& Rui, O. M. 2006. Ownership structure, corporate governance and fraud: Evidence from China. Journal of Corporate Finance, 12(3): 424-448. 
Cheung, C. \& Chan, A. C. 2008. Benefits of Hong Kong Chinese CEOs' Confucian and Daoist leadership styles. Leadership \& Organization Development Journal, 29: 474-503.

Chughtai, A. A. \& Buckley, F. 2010. Assessing the effects of organizational identification on inrole job performance and learning behaviour. Personnel Review, 39(2): 242-258.

Company Law. 2006. The Company Law of The People's Republic of China. People's Republic of China.

Cohen, J. \& Cohen, P. 1983. Applied multiple regression/correlation analysis for the behavior sciences (2nd ed.). Hillsdale, NJ: Lawrence Erlbaum Associates.

Cooper, D. \& Thatcher, S. M. B. 2010. Identification in organizations: The role of self-concept orientations and identification motives. Academy of Management Review, 35(4): 516538.

CSRC. 2001. Guidelines for introducing independent directors to the board of directors of listed companies. P.R. China: China Securities Regulatory Commission.

Dalton, D. R. \& Dalton, C. M. 2011. The integration of micro and macro studies in corporate governance research: CEO duality, board composition, and financial performance. Journal of Management, 37(2): 404-411.

DeShon, R. P. \& Gillespie, J. Z. 2005. A motivated action theory account of goal orientation. Journal of Applied Psychology, 90(6): 1096-1127.

Dweck, C. S. 1999. Self-theories: Their Role in Motivation and Development. Philadelphia: Psychology Press.

Dweck, C. S. \& Leggett, E. L. 1988. A social-cognitive approach to motivation and personality. Psychological Review, 95(2): 256-273.

Elliot, A. 1999. Approach and avoidance motivation and achievement goals. Educational Psychologist, 34(3): 169-189.

Elliot, A. J. \& Dweck, C. S. 1988. Goals: An approach to motivation and achievement. Journal of Personality and Social Psychology, 54: 5-12.

Elliot, A. J. \& McGregor, H. 1999. Test anxiety and the hierachical model of approach and avoidance achievment motivation. Journal of Personality and Social Psychology, 76(6): 628-644.

Ferris, S. P., Jagannathan, M. \& Pritchard, A. C. 2003. Too busy to mind the business? Monitoring by directors with multiple board appointments. Journal of Finance, 58(3): 1087-1112.

Filatotchev, I. \& Nakajima, C. 2010. Internal and external corporate governance: An interface between an organization and its environment. British Journal of Management, 21(3): 591-606. 
Finkelstein, S. \& Hambrick, D. C. 1996. Strategic leadership: Top executives and their effects on organizations. Minneapolis: West Publishing Company.

Finkelstein, S. \& Mooney, A. C. 2003. Not the usual suspects: How to use board process to make boards better. Academy of Management Executive (1993-2005), 17(2): 101-113.

Flynn, F. L. 2005. Identity orientations and forms of social exchange in organizations. Academy of Management Review, 30(4): 737-750

Forbes, D. P. \& Milliken, F. J. 1999. Cognition and corporate governance: Understanding boards of directors as strategic decision-making groups. Academy of Management Review, 24(3): 489-505.

Fritz, M. S. \& MacKinnon, D. P. 2007. Required sample size to detect the mediated effect. Psychological Science, 18: 233-239.

Fritz, M. S., Taylor, A. B., \& MacKinnon, D. P. 2012. Explanation of two anomalous results in statistical mediation analysis. Multivariate Behavioral Research, 47(1): 61-87.

Globerman, S., Peng, M., \& Shapiro, D. 2011. Corporate governance and Asian companies. Asia Pacific Journal of Management, 28(1): 1-14.

Golden-Biddle, K. \& Rao, H. 1997. Breaches in the boardroom: Organizational identity and conflicts of commitment in a nonprofit organization. Organization Science, 8(6): 593611.

Gong, Y., Huang, J. C. \& Farh, J. L. 2009. Employee learning orientation, transformational leadership, and employee creativity: The mediating role of employee creative selfefficacy. Academy of Management Journal, 52(4): 765-778.

Greene, B. A. \& Miller, R. B. 1996. Influences on achievement: Goals, perceived ability, and cognitive engagement. Contemporary Educational Psychology, 21(2): 181-192.

Hancock, G. R. \& Mueller, R. O. 2001. Rethinking construct validity within latent variable systems. Lincolnwood,IL: Scientific Software International Inc.

Harackiewicz, J.M., Barron, K.E. \& Elliot, A.J. 1998. Rethinking achievement goals: When are they adaptive for college students and why? Educational Psychologist, 33(1): 1-21.

Haynes, K. T. \& Hillman, A. 2010. The effect of board capital and CEO power on strategic change. Strategic Management Journal, 31, 1145-1163.

Heugens, P. P. M. A. R., van Essen, M., \& van Oosterhout, J. 2009. Meta-analyzing ownership concentration and firm performance in Asia: Towards a more fine-grained understanding. Asia Pacific Journal of Management, 26(3): 481-512.

Hillman, A. J. \& Dalziel, T. 2003. Boards of directors and firm performance: Integrating agency and resource dependence perspectives. Academy of Management Review, 28(3): 383396. 
Hillman, A. J., Nicholson, G. \& Shropshire, C. 2008. Director's multiple identities, Identification, and board monitoring and resource provision. Organization Science, 19(3): 411-456.

Hofstede, G., Van Deusen, C. A., Mueller, C. B. \& Charles, T. A. 2002. What goals do business leaders pursue? A study in fifteen countries. Journal of International Business Studies, 33(4): 785-803.

Hu, H., Tam, O. \& Tan, M. 2010. Internal governance mechanisms and firm performance in China. Asia Pacific Journal of Management, 27(4): 727-749.

Hu, L. T. \& Bentler, P. M. 1999. Cutoff criteria for fit indexes in covariance structure analysis: Conventional criteria versus new alternatives. Structural Equation Modeling: A Multidisciplinary Journal, 6(1): 1-55.

Huse, M. 2007. Boards, governance and value creation: The human side of corporate governance. Cambridge: Cambridge University Press.

Huse, M. 2009. The Value Creating Board: Corporate Governance and Organizational Behaviour. New York: Routledge.

Jackling, B. \& Johl, S. 2009. Board structure and firm performance: Evidence from India's top companies. Corporate Governance: An International Review, 17(4): 492-509.

Jensen, M. C. \& Meckling, W. H. 1976. Theory of the firm: Managerial behavior, agency costs and ownership structure. Journal of Financial Economics, 3(4): 305-360.

Johnson, J. L., Daily, C. M. \& Ellstrand, A. E. 1996. Board of directors: A review and research agenda. Journal of Management, 22(3): 409-438.

Kaplan, A. \& Maehr, M. 2007. The contributions and prospects of goal orientation theory. Educational Psychology Review, 19(2): 141-184.

Kato, T., \& Long, C. 2006. CEO turnover, firm performance, and enterprise reform in china: Evidence from micro data. Journal of Comparative Economics, 34(4): 796-817.

Kriauciunas, A., Parmigiani, A. \& Rivera-Santos, M. 2011. Leaving our comfort zone: Integrating established practices with unique adaptations to conduct survey-based strategy research in nontraditional contexts. Strategic Management Journal, 32(9): 9941010.

Kumar, P. \& Zattoni, A. 2013. How much do country-level or firm-level variables matter in corporate governance studies? Corporate Governance: An International Review, 21(3): 199-200.

Lawrence, P. R. \& Lorsch, J. W. 1967. Differentiation and integration in complex organizations. Administrative Science Quarterly, 12(1): 1-47.

Li, S., and Nair, A. 2009. Asian corporate governance or corporate governance in Asia? Corporate Governance: An International Review, 17(4): 407-410. 
Liu, G. S., and Sun, P. 2005. The class of shareholdings and its impacts on corporate performance: A case of state shareholding composition in Chinese public corporations. Corporate Governance: An International Review, 13(1): 46-59.

Mael, F. \& Ashforth, B. E. 1992. Alumni and their alma mater: A partial test of the reformulated model of organizational identification. Journal of Organizational Behavior, 13(2): 103123.

Mael, F. \& Ashforth, B. E. 2001. Identification in work, war, sports, and religion: Contrasting the benefits and risks. Journal for the Theory of Social Behaviour, 31(2): 197-222.

MacKinnon, D. P., Lockwood, C. M., Hoffman, J. M., West, S. G. \& Sheets, V. 2002. A comparison of methods to test mediation and other intervening variable effects. Psychological Methods, 7(1): 83-104.

McDonald, M. L., Khanna, P.,\& Westphal, J. D. 2008. Getting them to think outside the circle: Corporate governance, CEO advice networks, and firm performance. Academy of Management Journal, 51: 453-475.

McDonald, M. L. \& Westphal, J. D. 2003. Getting by with the advice of their friends: CEOs' advice networks and firms' strategic responses to poor performance. Administrative Science Quarterly, 48(1): 1-32.

McDonald, M. L. \& Westphal, J. D. 2010. A little help in here? Board control, CEO identification with the corporate elite, and strategic help provided to CEOs at other firms. Academy of Management Journal, 53(2): 343-370.

Meyer, J. P., Becker, T. E. \& Vandenberghe, C. 2004. Employee commitment and motivation: A conceptual analysis and integrative model. Journal of Applied Psyhology, 89(6): 9911007.

Miles, L. 2006. The Application of Anglo American corporate practices in societies influenced by Confucian values. Business and Society Review, 111, 3: 305-322.

Ng, K. Y., Ang, S., \& Chan, K. Y. 2008. Personality and leader effectiveness: A moderated mediation model of leadership self-efficacy, job demands, and job autonomy. Journal of Applied Psychology, 93(4): 733-743.

OECD. 2011. Governance of listed companies in China: Self-assessment by the China securities. OECD-China Policy Dialogue on Corporate Governance. Paris: OECD.

Oyserman, D. 2007. Social identity and self-regulation. In A. Kruglanski \& T. Higgins (Eds.) Handbook of Social Psychology $\left(2^{\text {nd }}\right.$ Ed. $)$. New York: Guilford Press.

Payne, S. C., Youngcourt, S. S. \& Beaubien, J. M. 2007. A meta-analytic examination of the goal orientation nomological net. Journal of Applied Psychology, 92(1): 128-150.

Peng, M. W. 2004. Outside directors and firm performance during institutional transitions. Strategic Management Journal, 25(5): 453-471. 
Podsakoff, P. M., MacKenzie, S. B. \& Podsakoff, N. P. 2003. Common method biases in behavioral research: A critical review of the literature and recommended remedies. Journal of Applied Psychology, 88: 879-903.

Podsakoff, P. M., MacKenzie, S. B. \& Podsakoff, N. P. 2012. Sources of method bias in social science research and recommendations on how to control it. Annual Review of Psychology, 63(1): 539-569.

Preacher, K. J., Rucker, D. D., \& Hayes, A. F. 2007. Addressing moderated mediation hypotheses: Theory, methods, and prescriptions. Multivariate Behavioral Research, 42(1): 185-227.

Rajagopalan, N. \& Zhang, Y. 2008. Corporate governance reforms in India and China: Challenges and opportunities. Business Horizons, 51(1): 55-64.

Riketta, M. 2005. Organizational identification: A meta-analysis. Journal of Vocational Behavior, 66: 358-384.

Shleifer, A. \& Vishny, R. W. 1997. A survey of corporate governance. Journal of Finance, 52(2): 737-783.

Shrout, P. E. \& Bolger, N. 2002. Mediation in experimental and nonexperimental studies: New procedures and recommendations. Psychological Methods, 7: 422-445.

Singh, D. A., \& Gaur, A. S. 2009. Business group affiliation, firm governance, and firm performance: Evidence from China and India. Corporate Governance: An International Review, 17(4): 411-425.

Steiger, J. H. 1980. Tests for comparing elements of a correlation matrix. Psychological Bulletin, 87: 245-251.

Stern, I. \& Westphal, J. D. 2010. Stealthy footsteps to the boardroom: Executives' backgrounds, sophisticated interpersonal influence behaviour, and board appointments. Administrative Science Quarterly, 55: 278-319.

Stevenson, W. B. \& Radin, R. F. 2009. Social capital and social influence on the board of directors. Journal of Management Studies, 46(1): 16-44.

Stiles, P. 2001. The impact of the board on strategy: An empirical examination. Journal of Management Studies, 38(5): 627-650.

Strahan, R. \& Gerbasi, K. C. 1972. Short, homogenous versions of the Marlowe-Crowne social desirability scale. Journal of Clinical Psychology, 28(2): 191-193.

Su, Y., Xu, D. \& Phan, P. H. 2008. Principal-principal conflict in the governance of the Chinese public corporation. Management and Organization Review, 4(1): 17-38.

Tian, J. J., \& Lau, C. 2001. Board composition, leadership structure and performance in Chinese shareholding companies. Asia Pacific Journal of Management, 18(2): 245-263. 
Tsui, A. S., Schoonhoven, C. B., Meyer, M. W., Lau, C. M., \& Milkovich, G. T. 2004. Organization and management in the midst of societal transformation: The People's Republic of China. Organization Science, 15(2), 133-144.

van Essen, M., van Oosterhout, J. H. , \& Carney, M. 2012. Corporate boards and the performance of asian firms: A meta-analysis. Asia Pacific Journal of Management, 29(4): 873-905.

van Knippenberg, D. 2000. Work motivation and performance: A social identity perspective. Applied Psychology, 49(3): 357-371.

Vandewalle, D. 1997. Development and validation of a work domain goal orientation instrument. Educational Psychological Measurement, 57(6): 995-1014.

Vandewalle, D. 2001. Why wanting to look successful doesn't always lead to success. Organizational Dynamics, 30(2): 162-171.

Vandewalle, D., Cron, W. L. \& Slocum, J. W. 2001. The role of goal orientation following performance feedback. Journal of Applied Psychology, 86(4): 629-640.

Wang, J., G. Wang, W. Ruona, \& Rojewski, J. 2005. Confucian Values and Implications for HRD. Human Resource Development International, 8(3): 311-326.

Withers, M. C., Corley, K. G., \& Hillman, A. J. 2012. Stay or leave: Director identities and voluntary exit from the board during organizational crisis. Organization Science, 23(3): 835-850.

Westphal, J. D. \& Stern, I. 2007. Flattery will get you everywhere (especially if you are a male caucasian): How ingratiation, boardroom behavior and demographic minority status affect additional board appointments at U.S. companies. Academy of Management Journal, 50(2): 267-288.

Westphal, J. D. \& Zajac, E. J. 1997. Defections from the inner Circle: Social exchange, reciprocity, and the diffusion of board independence in U.S. corporations. Administrative Science Quarterly, 42(1): 161-183.

Williams, L. J., Vandenberg, R. J. \& Edwards, J. R. 2009. Structural equation modeling in management research: A guide for improved analysis. Academy of Management Annals, 3: 543 - 604 .

Xiao, J. Z., Yang, H. \& Chow, C. W. 2004. The determinants and characteristics of voluntary Internet-based disclosures by listed Chinese companies. Journal of Accounting and Public Policy, 23(3): 191-225.

Young, M.N., Ahlstrom, D., Bruton, G.D. \& Chan, E.S. 2001. The resource dependence, service, and control functions of boards of directors in Hong Kong and Taiwanese firms. Asia Pacific Journal of Management, 18: 223-244. 
Young, M. N., Peng, M. W., Ahlstrom, D., Bruton, G. D. \& Jiang, Y. 2008. Corporate governance in emerging economies: A Review of the principal-principal perspective. Journal of Management Studies, 45(1): 196-220.

Zattoni, A. \& Van Ees, H. 2012. How to contribute to the development of a global understanding of corporate governance? Reflections from submitted and published articles in CGIR. Corporate Governance: An International Review, 20(1): 106-118. 
TABLE 1

Summary of Respondents $(\mathrm{N}=300)$

\begin{tabular}{|c|c|c|c|c|c|}
\hline Type of directorship & & Experience as a director & & Functional background & \\
\hline Executive director & 90 & 2 years and below & 71 & Operation and management & 63 \\
\hline Non-executive director & 10 & 3-4 years & 120 & Engineering and R\&D & 76 \\
\hline \multirow[t]{2}{*}{ Independent director } & 200 & $5-6$ years & 59 & Sales and marketing & 2 \\
\hline & & $7-8$ years & 42 & Law & 33 \\
\hline Director term $^{1}$ & & $9-10$ years & 6 & Finance and accounting & 60 \\
\hline First term & 121 & More than 10 years & 2 & Others & 66 \\
\hline Second term & 121 & & & & \\
\hline Third term & 48 & Currently serves on the board of & & Gender & \\
\hline \multirow[t]{2}{*}{ Fourth term } & 10 & 1 listed company & 191 & Male & 270 \\
\hline & & 2 listed companies & 52 & Female & 30 \\
\hline Director tenure left & & 3 listed companies & 29 & & \\
\hline 6 months and less & 27 & 4 listed companies & 13 & Educational background & \\
\hline $7-12$ months & 43 & 5 listed companies & 8 & High school or below & 23 \\
\hline 13-24 months & 128 & More than 5 listed companies & 7 & Bachelors & 96 \\
\hline 25-36 months & 101 & & & Masters (including MBA) & 115 \\
\hline More than 36 months & 1 & & & Doctorate & 66 \\
\hline
\end{tabular}


TABLE 2

Measurement Scales

\begin{tabular}{|c|c|c|c|c|}
\hline Constructs and Indicators & Factor & $t$ & $\mathbf{R}^{2}$ & Reliability \\
\hline Organizational identification & & & & 0.87 \\
\hline When someone criticizes this company, it feels like a personal insult. & 0.72 & 20.70 & 0.61 & \\
\hline I am very interested in what others think about this company. & 0.79 & 26.07 & 0.69 & \\
\hline When I talk about this company, I usually say 'we' rather than 'they'. & 0.67 & 18.84 & 0.57 & \\
\hline When someone praises this company it feels like a personal compliment. & 0.73 & 20.02 & 0.63 & \\
\hline If a story in the media criticized this company, I would feel embarrassed. & 0.72 & 21.86 & 0.62 & \\
\hline Executive-agent identification & & & & 0.83 \\
\hline When someone criticizes company executive, it feels like a personal insult. & 0.77 & 22.93 & 0.65 & \\
\hline I am very interested in what others think about company executives. & 0.68 & 18.93 & 0.58 & \\
\hline When I talk about company executives, I usually say 'we' rather than 'they'. & 0.69 & 19.34 & 0.60 & \\
\hline When someone praises company executives it feels like a personal compliment. & 0.72 & 20.65 & 0.62 & \\
\hline If a story in the media criticized company executives, I would feel embarrassed. & 0.65 & 16.69 & 0.55 & \\
\hline Learning goal orientation & & & & 0.81 \\
\hline I often read materials beyond those provided in board packs to improve my ability. & 0.84 & 15.41 & 0.71 & \\
\hline I am willing to solicit advice and guidance from people that I can learn from. & 0.62 & 11.32 & 0.54 & \\
\hline I often look for opportunities to develop new skills and knowledge. & 0.78 & 13.49 & 0.61 & \\
\hline Avoidance Orientation & & & & 0.78 \\
\hline I would avoid situations where I would appear rather incompetent to others & 0.68 & 15.95 & 0.46 & \\
\hline Avoiding a show of low ability is important to me & 0.69 & 16.99 & 0.48 & \\
\hline I would be concerned about my involvement if it could reveal I had low ability & 0.66 & 15.14 & 0.43 & \\
\hline I prefer to avoid situations where I could risk performing poorly & 0.72 & 18.02 & 0.52 & \\
\hline Monitoring & & & & 0.92 \\
\hline To what extent have you requested information for the purpose of evaluating & 0.95 & 26.96 & 0.90 & \\
\hline To what extent have you sought information for the purpose of evaluating the & 0.64 & 15.71 & 0.41 & \\
\hline To what extent have you constructively criticized a strategic proposal put forth & 0.60 & 11.10 & 0.37 & \\
\hline
\end{tabular}


TABLE 3

Descriptive Statistics and Correlations $(\mathrm{N}=300)$

\begin{tabular}{|c|c|c|c|c|c|c|c|c|c|c|c|}
\hline & \multirow{2}{*}{ Mean } & \multirow{2}{*}{ S.D. } & \multicolumn{9}{|c|}{ Correlations $^{1}$} \\
\hline & & & 1 & 2 & 3 & 4 & 5 & 6 & 7 & 8 & 9 \\
\hline 1.Organizational identification ${ }^{2}$ & 4.15 & 0.52 & 1.00 & & & & & & & & \\
\hline 2.Executive-agent identification ${ }^{2}$ & 3.80 & 0.56 & 0.22 & 1.00 & & & & & & & \\
\hline 3.Learning goal orientation ${ }^{2}$ & 4.16 & 0.48 & 0.58 & 0.27 & 1.00 & & & & & & \\
\hline 4.Avoidance orientation ${ }^{2}$ & 3.95 & 0.53 & 0.38 & 0.36 & 0.42 & 1.00 & & & & & \\
\hline 5.Monitoring role ${ }^{2}$ & 4.00 & 0.52 & 0.57 & 0.24 & 0.56 & 0.43 & 1.00 & & & & \\
\hline 6.Directorships & 1.74 & 1.30 & 0.05 & -0.04 & -0.02 & -0.07 & 0.03 & 1.00 & & & \\
\hline 7.Remaining tenure (months) & 19.36 & 9.05 & 0.01 & 0.07 & -0.02 & 0.05 & 0.00 & 0.03 & 1.00 & & \\
\hline 8.Independent dummy & 0.67 & 0.47 & -0.09 & -0.11 & -0.08 & -0.09 & 0.01 & -0.04 & -0.03 & 1.00 & \\
\hline 9.Social desirability scale ${ }^{3}$ & 7.64 & 1.39 & 0.08 & 0.03 & 0.02 & 0.17 & 0.09 & 0.03 & -0.00 & -0.04 & 1.00 \\
\hline
\end{tabular}

${ }^{1}$ Correlations greater than 0.16 are significant at $p<0.05$.

${ }^{2}$ Construct level composite (average score of corresponding indicators)

${ }^{3}$ Strahan and Gerbasi's (1972) 10-item scale. 
TABLE 4

SEM Analyses of the Moderating Effect of Avoidance Orientation

\begin{tabular}{llll}
\hline & Model 1 & Model 2 & Model 3 \\
\hline Effect on learning goal orientation (LGO) & & & \\
Organizational identification (OrgID) & $0.463^{* * *}$ & $0.448^{* * *}$ & $0.518^{* * *}$ \\
Executive-agent identification (ExeID) & $0.184^{*}$ & $0.193^{*}$ & $0.253^{*}$ \\
Avoidance orientation (AO) & $0.189^{* *}$ & $0.189^{* *}$ & \\
OrgID $\times$ AO & $-0.374^{* *}$ & & \\
ExeID $\times$ AO & & $-0.355^{* *}$ & \\
\hline Effect on monitoring & & & \\
LGO & 0.292 & 0.285 & 0.318 \\
AO & 0.204 & 0.203 & $0.222^{*}$ \\
OrgID & $0.350^{*}$ & $0.349^{*}$ & $0.326^{*}$ \\
ExeID & 0.104 & 0.109 & 0.090 \\
OrgID $\times$ AO & -0.111 & & \\
ExeID $\times$ AO & & -0.085 & \\
LGO $\times$ AO & & & -0.171 \\
Directorships & 0.022 & 0.022 & 0.022 \\
Remaining tenure (months) & -0.002 & -0.002 & -0.002 \\
Independent dummy & $0.060^{*}$ & $0.058^{*}$ & $0.060^{*}$ \\
Social desirability scale & $0.051^{* *}$ & $0.054^{* *}$ & $0.052^{* *}$ \\
\hline Note: * $<0.05 * * * p<0.01 ; * * * 00.001$ & &
\end{tabular}

Note: $* \mathrm{p}<0.05 ; * * \mathrm{p}<0.01 ; * * * \mathrm{p}<0.001$ 
TABLE 5

Test of Conditional Indirect Effect using SEM with Bootstrap ${ }^{\text {a }}$

\begin{tabular}{|c|c|c|c|c|c|c|c|}
\hline Indirect effect & Lower .5\% & Lower $2.5 \%$ & Lower $5 \%$ & Estimate & Upper 5\% & Upper $2.5 \%$ & Upper .5\% \\
\hline \multicolumn{8}{|c|}{ Organizational identification to monitoring through learning goal orientation: } \\
\hline \multicolumn{8}{|c|}{ Avoidance orientation $=$ high $($ mean $+1 \mathrm{sd})$} \\
\hline & -0.722 & -0.321 & -0.057 & 0.175 & 0.477 & 0.742 & 0.952 \\
\hline \multicolumn{8}{|c|}{ Avoidance orientation $=$ low $($ mean $-1 \mathrm{sd})$} \\
\hline & -0.122 & 0.061 & 0.172 & 0.265 & 0.318 & 0.553 & 0.733 \\
\hline \multicolumn{8}{|c|}{ Executive-agent identification to monitoring through learning goal orientation: } \\
\hline \multicolumn{8}{|c|}{ Avoidance orientation $=$ high $($ mean $+1 \mathrm{sd})$} \\
\hline & -0.512 & -0.256 & -0.028 & 0.088 & 0.145 & 0.366 & 0.632 \\
\hline \multicolumn{8}{|c|}{ Avoidance orientation $=$ low $($ mean- $1 \mathrm{sd})$} \\
\hline & -0.049 & 0.007 & 0.058 & 0.134 & 0.213 & 0.354 & 0.671 \\
\hline
\end{tabular}

${ }^{\mathrm{a}}$ Number of bootstrap draws $=1000$. 
FIGURE 1

SEM Test of Mediating Effect of Learning Goal Orientation

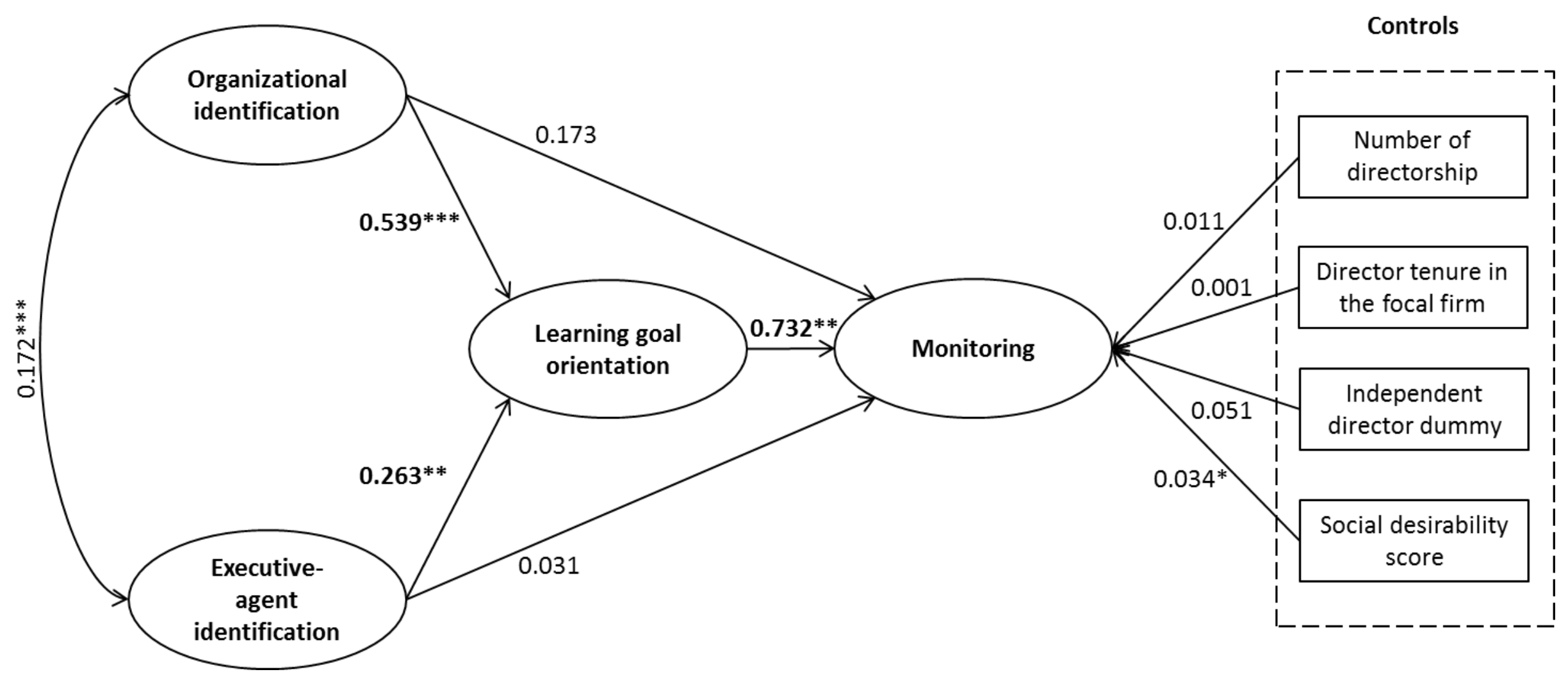


FIGURE 2

The Conditional Indirect Effects of Director Identifications on Monitoring via Learning Goal Orientation

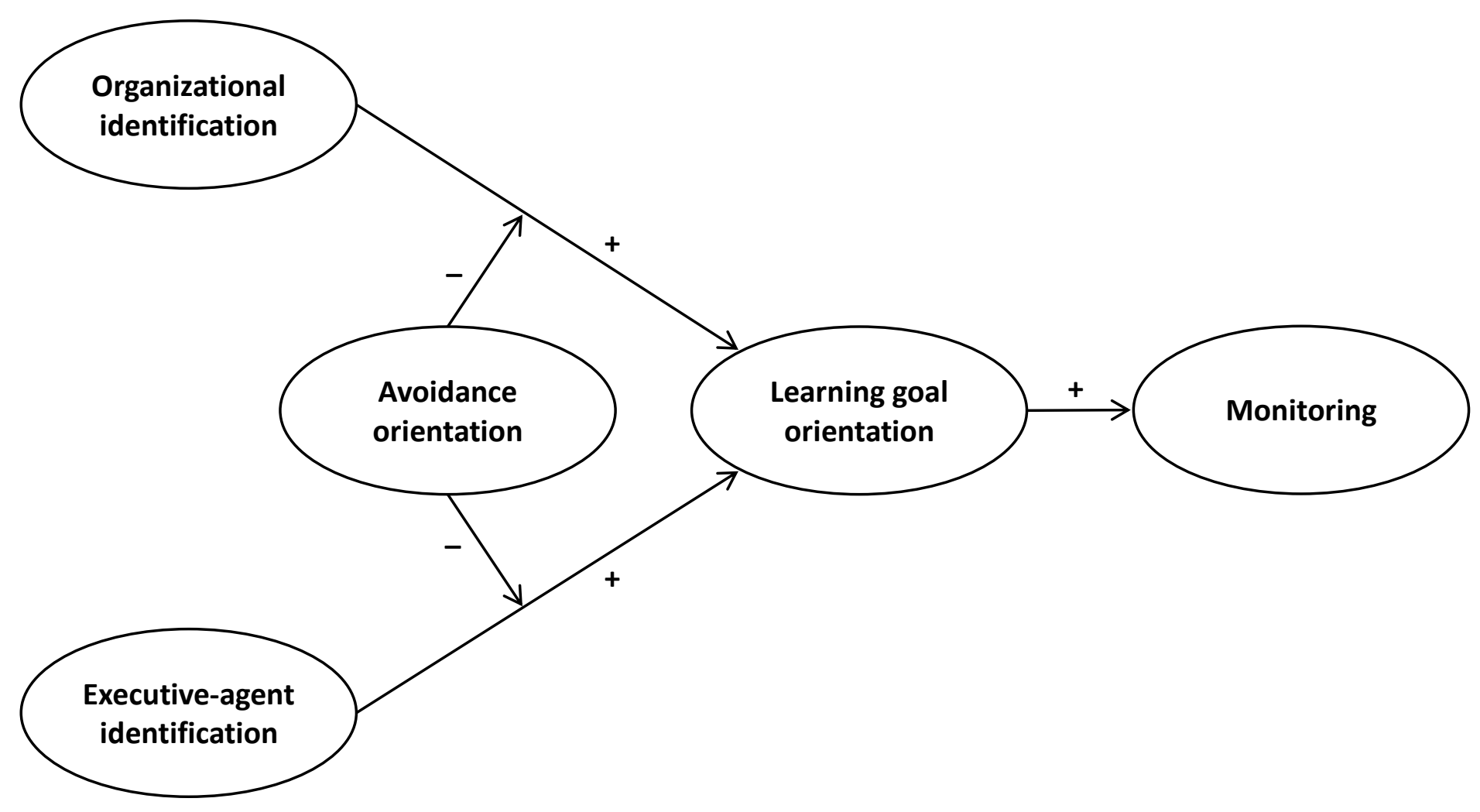




\section{University Library}

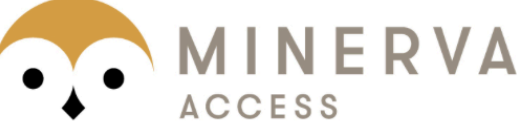

A gateway to Melbourne's research publications

Minerva Access is the Institutional Repository of The University of Melbourne

Author/s:

Capezio, A;Cui, L;Hu, HW;Shields, J

Title:

What governs directors' monitoring behavior in China? The influence of director social identification, learning goal orientation, and avoidance orientation

Date:

2014-12-01

Citation:

Capezio, A., Cui, L., Hu, H. W. \& Shields, J. (2014). What governs directors' monitoring behavior in China? The influence of director social identification, learning goal orientation, and avoidance orientation. ASIA PACIFIC JOURNAL OF MANAGEMENT, 31 (4), pp.899-924. https://doi.org/10.1007/s10490-014-9387-7.

Persistent Link:

http://hdl.handle.net/11343/282536 